\title{
生後直二發見サレタ巨大口腔底皮樣囊腫ノ1例
}

日本䇴科大學齊滕外科教室(主任 濟藤教授)

覧學士梶 原 岩 美

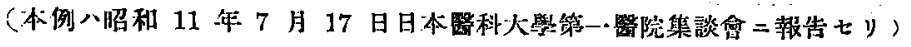

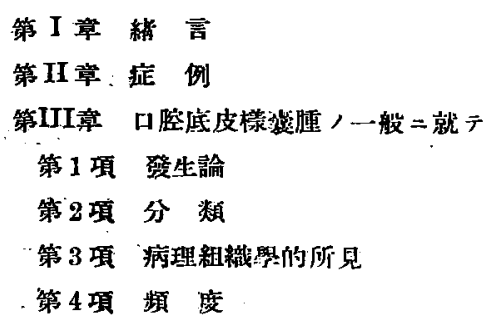

目次

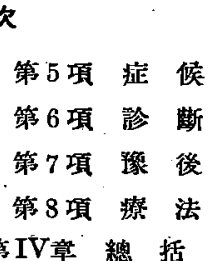

文 獻

第I章 緒 言

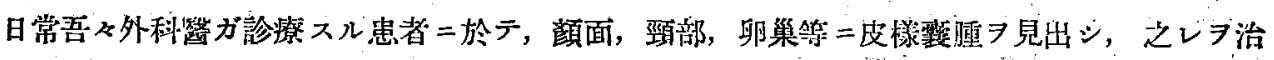

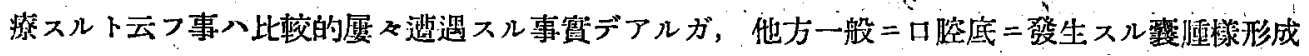

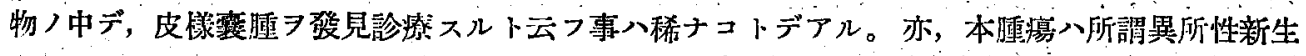

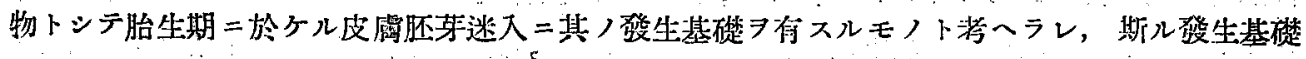

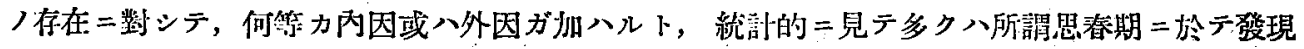

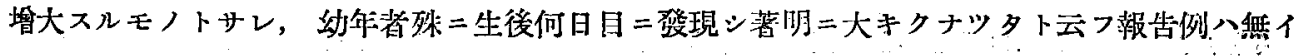

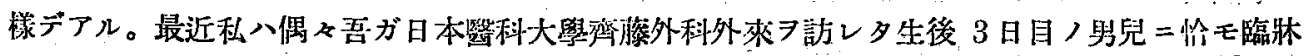

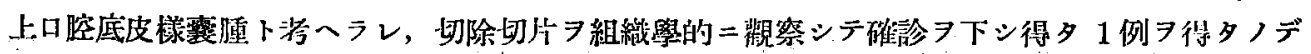
そレヨ報告シ，且ツ本腫演ノ一般二就テ聊カ述ベタイト思つ。

\section{第II章 症例}

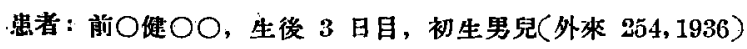

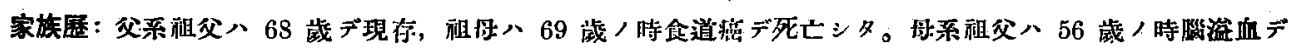

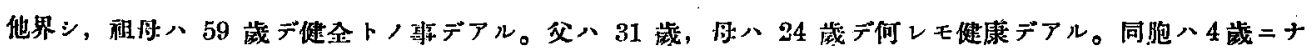

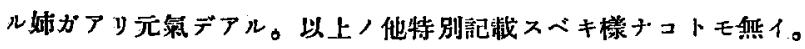

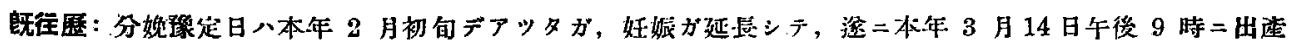

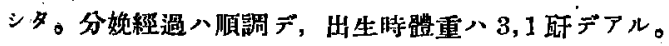

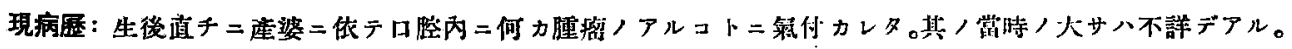

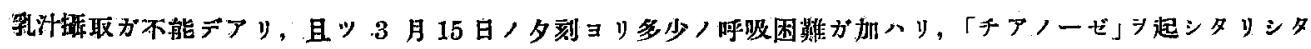

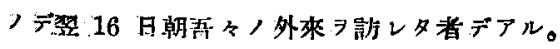




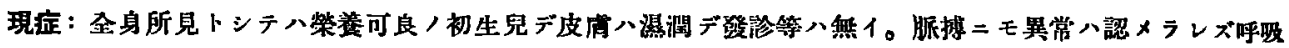

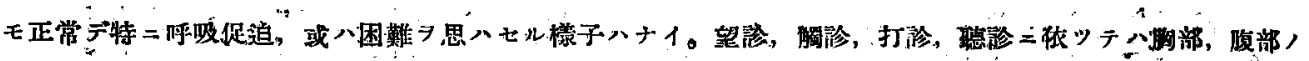
諸眮器及ビ四肢二八變化

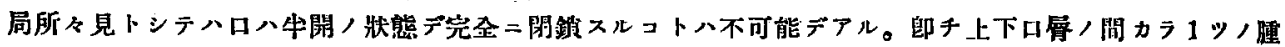

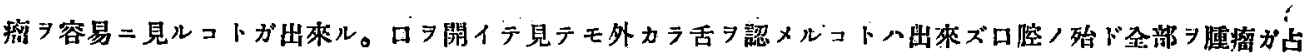

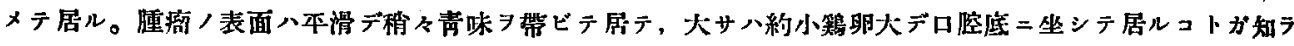

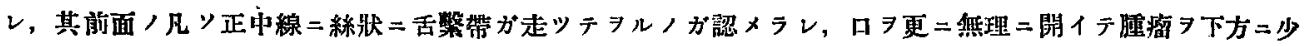

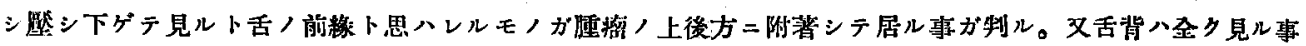

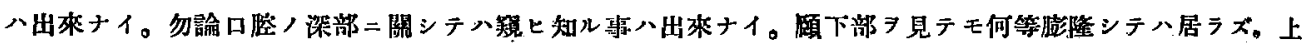

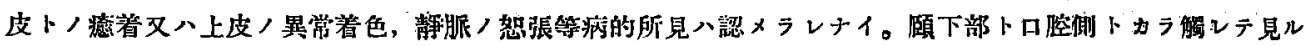

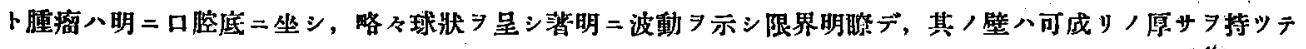

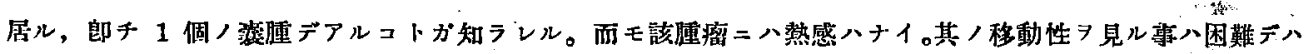

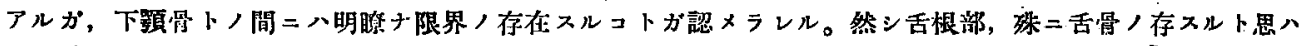

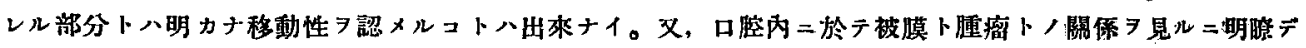

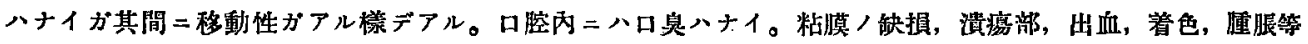

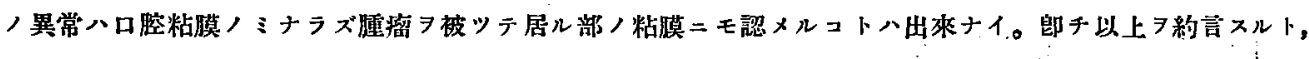

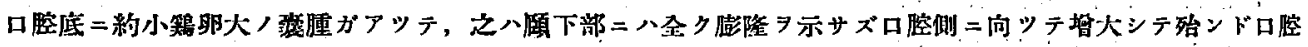

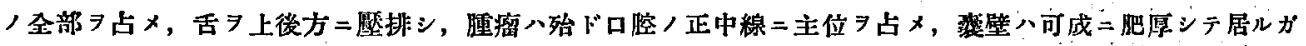

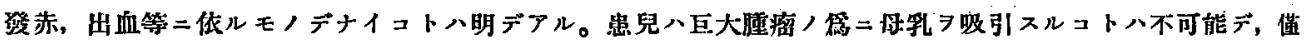

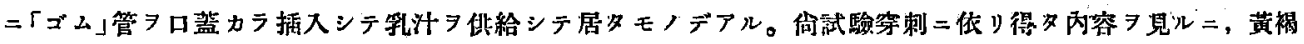

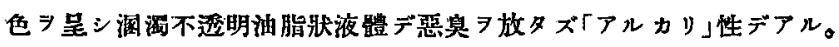

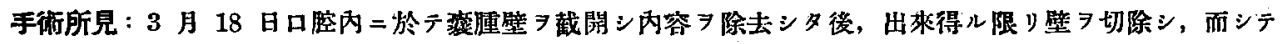

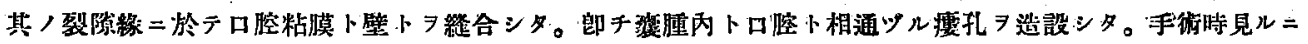

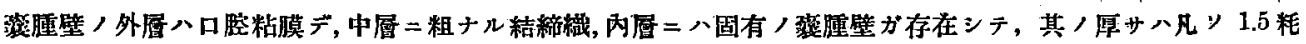

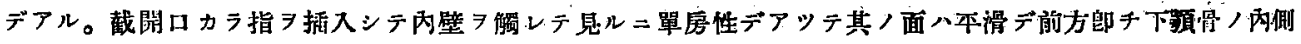

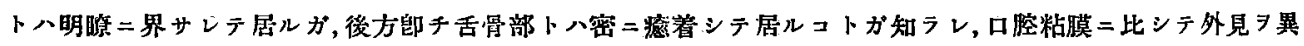

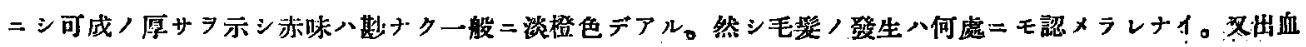

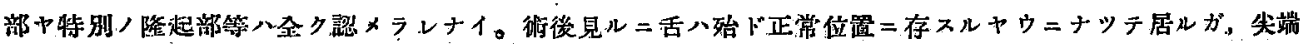

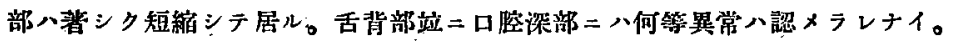

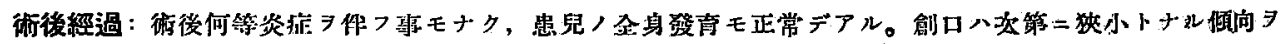

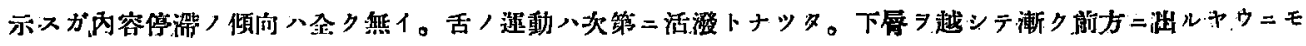

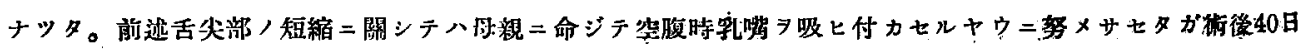

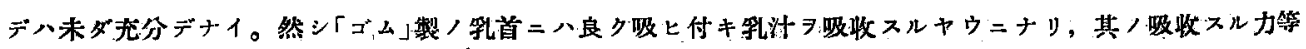

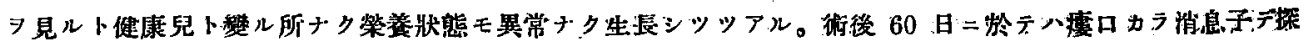

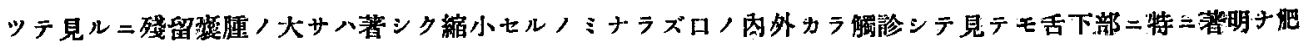




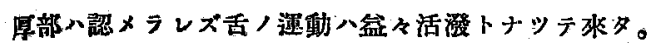

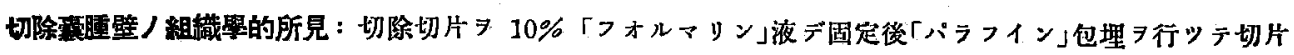

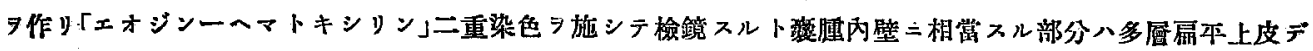
柀八レ其

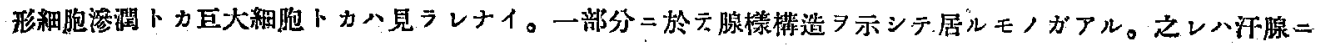

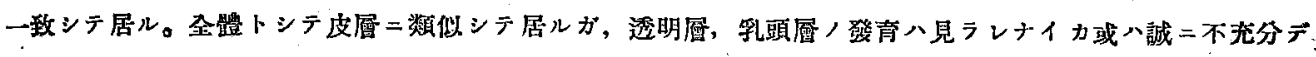

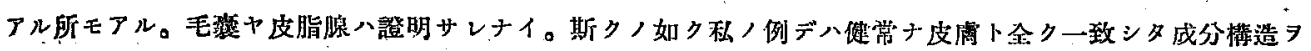

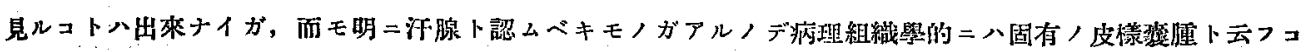
トガ出來ル。

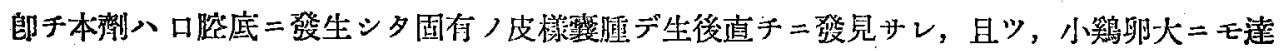
スル大キナモノデ稀驸ナ 1 例デテル。

\section{第 III 章 口貯底皮樣素腫ノ一般二就テ}

\section{第 1 項 發 生 論}

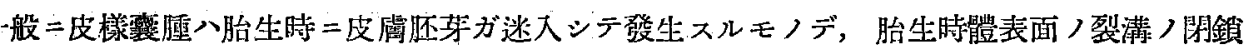
機轉ノ行ハレル場所カ，或ハ又，外还葉ノ陷入機轉ノ進行スル所が其ノ發坐部位卜考へラレ，

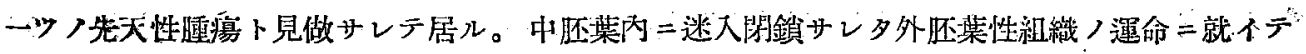

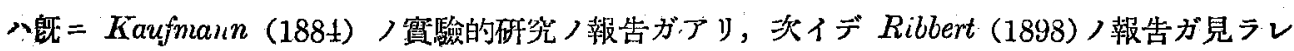

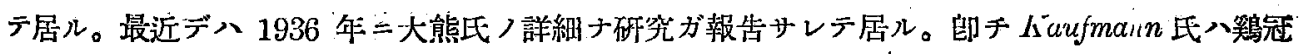

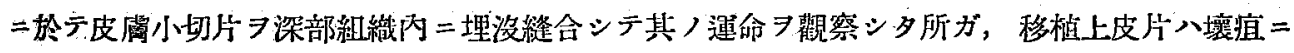

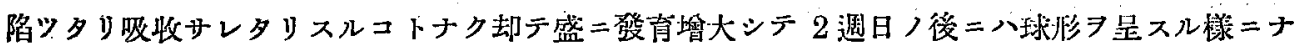

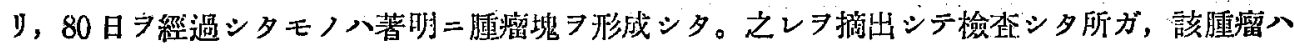

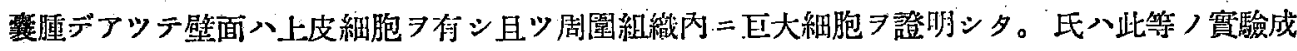

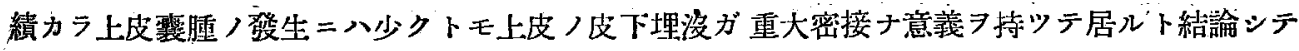

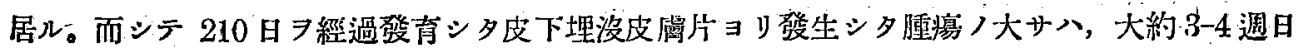

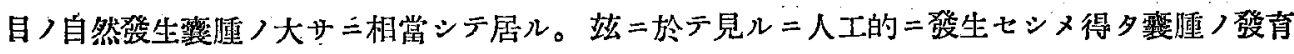

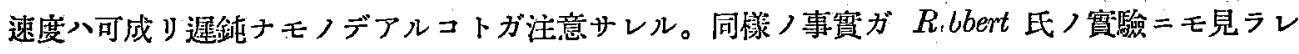
ルノデアツテ，氏：完全二剥離シタ皮膚片 7 同動物ノ淋巴腺內，皮下，腹䐦內及ビ前眼房內二

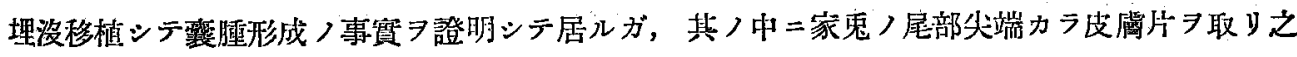

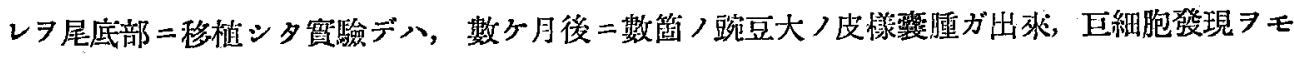

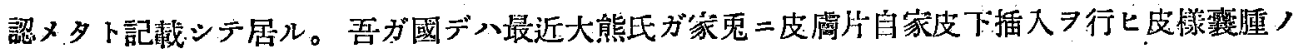

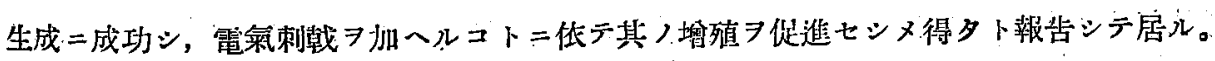

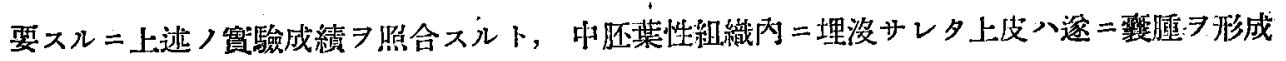

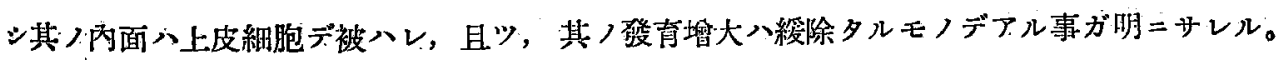




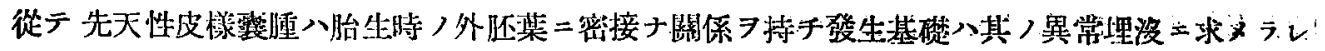

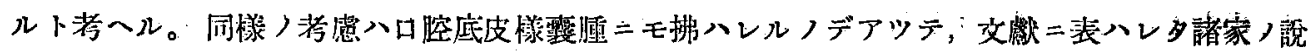

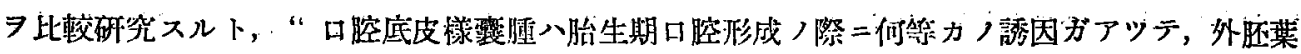

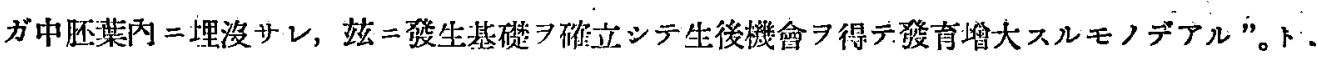
云フ意見二大體一致シテ居ル㥞デアル。即チ文䖍二裴ハレタ諸家ノ意見ヨ抄記ズレバ次ノ通リ デアル。

1900 年 $=$ Purtsch 八 Haudbuch der praktischen Chirugie $=$ Rosenberg $(1894)^{\circ}$ ) 說 $\ni$ 揭 $゙$

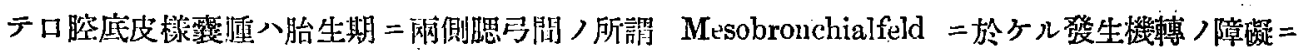

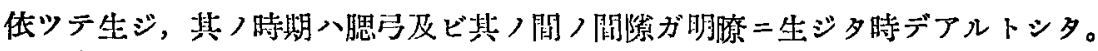

โ913年=Bergmann 八同壸=自說

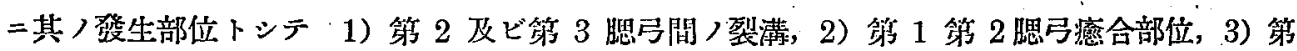

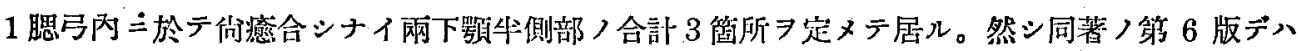
上記ノ自說习止メテ 1913 年二發表サレタ Hassel 說习採䏳記述シテ居ル。

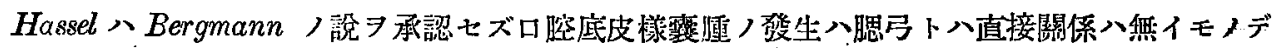

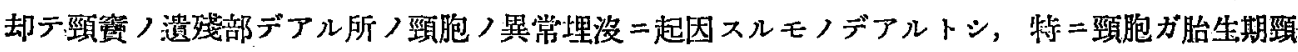

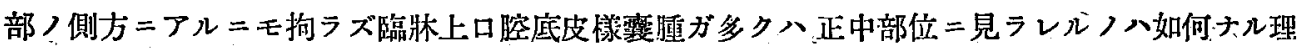
由カト云フ疑點二對スル說明ヨ附加シテ居ル。即チ胎生期二八頸部ハ楔形デアシテ頸胞入正中 線デハナイガ，少クトモ正中線二近ク接シテ存在シ胎兒ノ發育進度=俳フテ頭部中还葉ノ發育

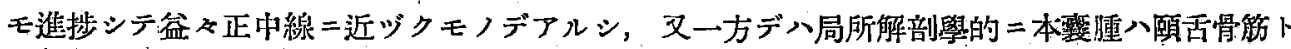

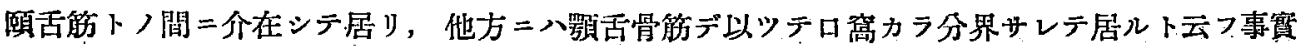
カラ考へテ，中还葉內二迷入シタ外脴葉八諸筋肉ノ發育二依ツテ或儿變位作朋ガ起り，從テ整 腫が肉眼的二觀察シ得ルヤウニナツタ時ニハ正中部位二位シテ居ルデアロウト述ベテ居ル。

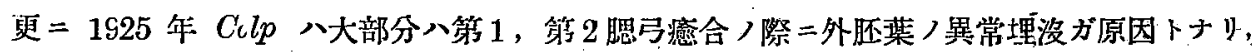

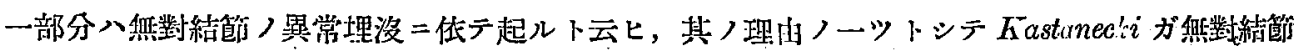

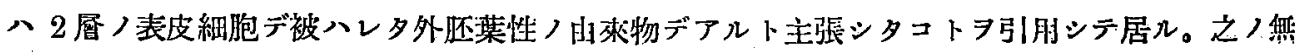

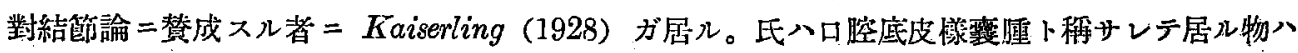
Kastonecki und Mielecki (1892) 等ガ信ジテ居ル所) Mesobronchiale Dermoide =一致ス火モ

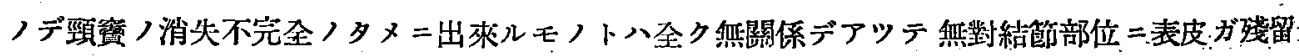
埋浓シテ起ルト考へタノデアル。

上述ノ諸說八總テ臨喿所見站二主トシテ胎生學上ノ根據カラ推斷サレタモノデアッテ，何等

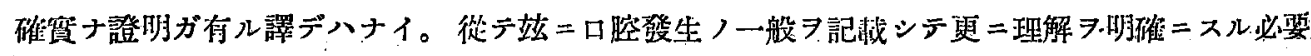
ガアル。

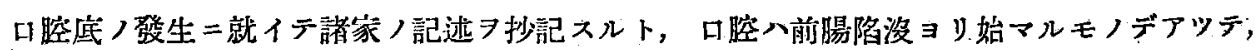
$-1036$ 


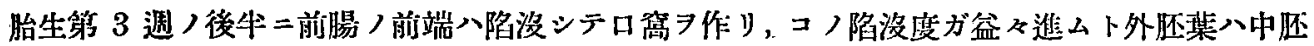

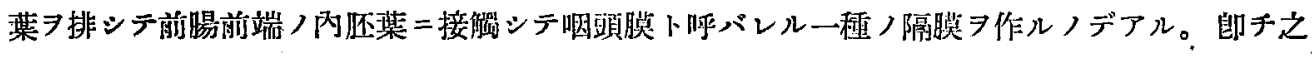

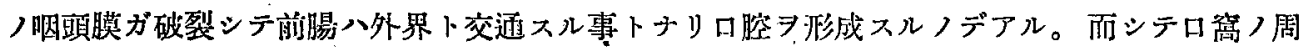

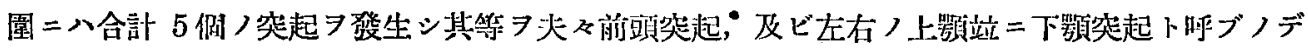

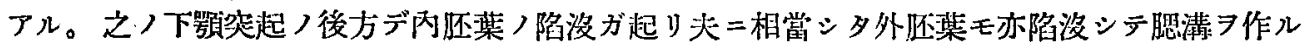

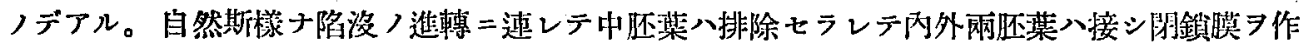

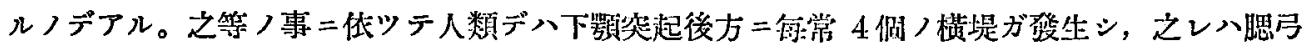

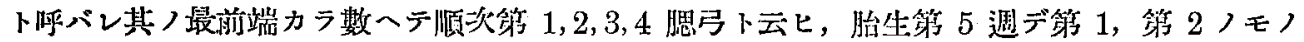

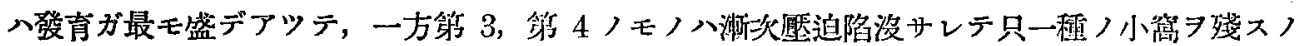

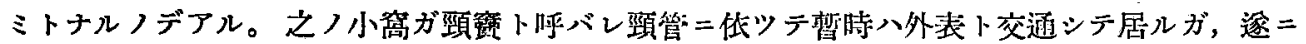
八较扼サレテ頸胞トナルノデアル。然シ之ノ頸胞モ最後二八消失スル運命ニアル。佮下顎弓八

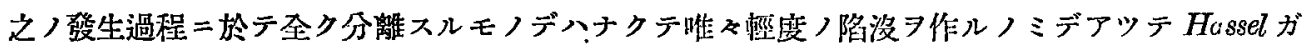
自說ノ主要ナ根據トシテ居ルコトデアル。次二然龂結節ト云フノハ舌ノ發生ニ當ツテ低在スル

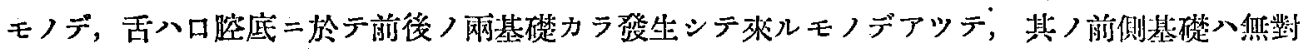
デアルノデ無對結節ト云ハレ第 1 ，第 2 腮户ノ中間カラ生ズルモノデアルトサレル。

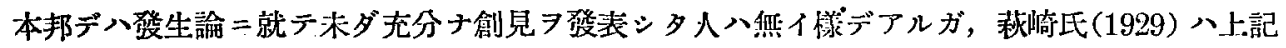

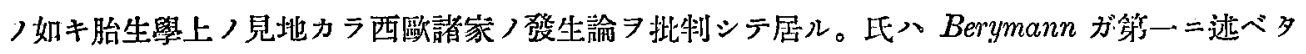

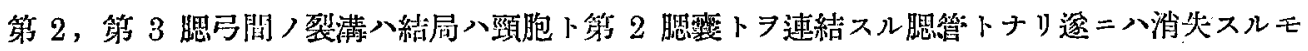

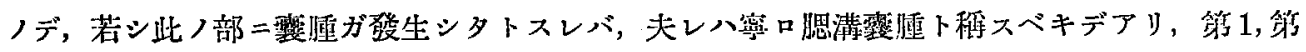

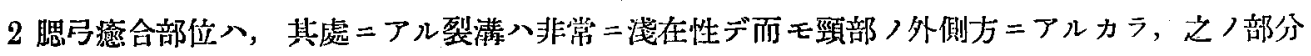

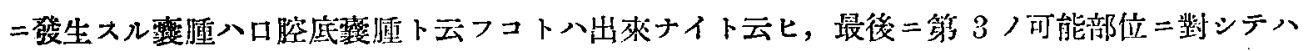

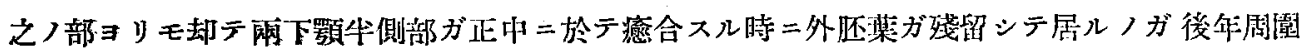
組維ノ移動作湖三依テロ腔底正中＝現ハレルモノト考へルノガ至當デアラウト云ツテ居ル。恐

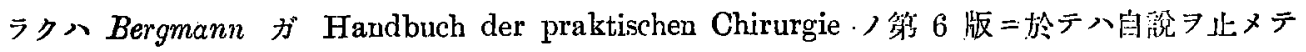

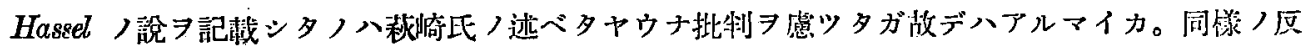

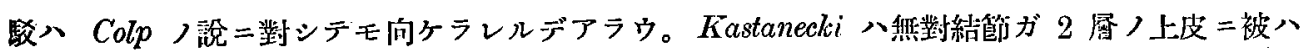

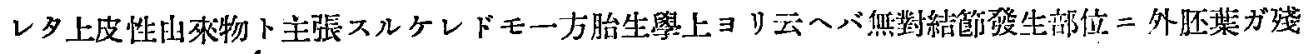

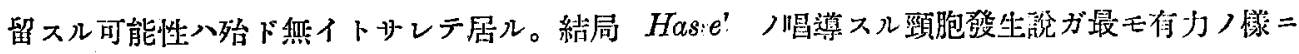

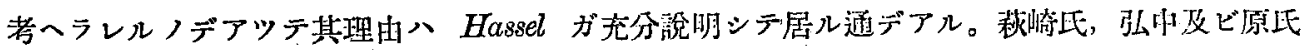

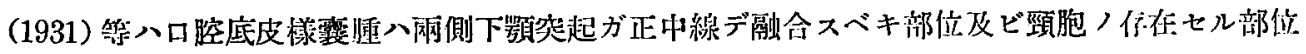
トノ 2 ツ擧ゲテ居ル。

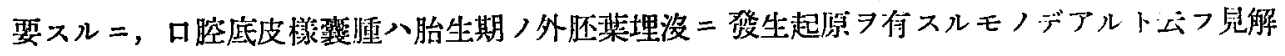

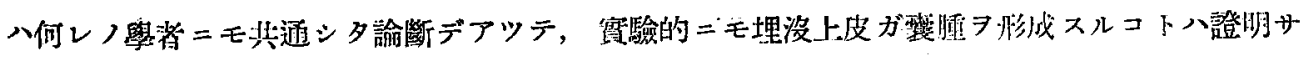




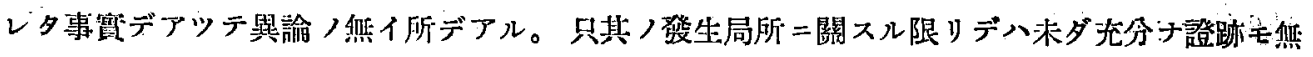

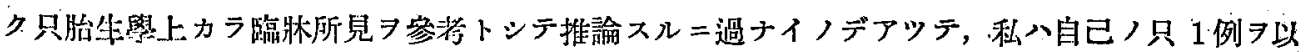

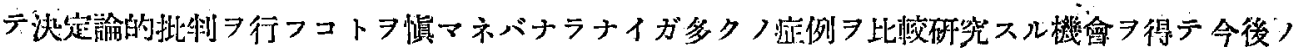
追冰习养望シタイ。

\section{第 2 項 分 類}

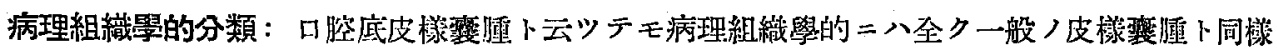

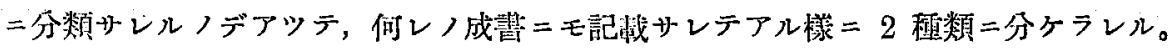

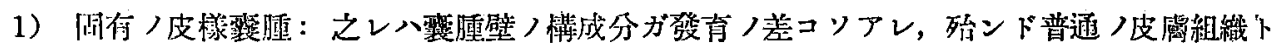

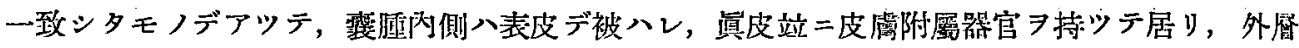

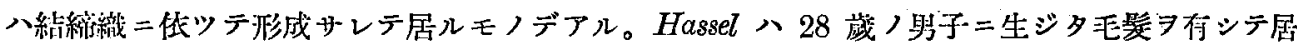

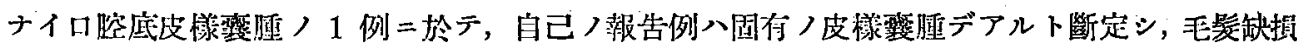

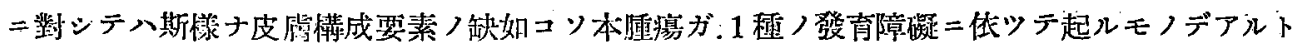

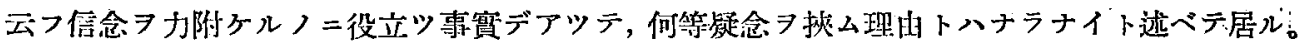

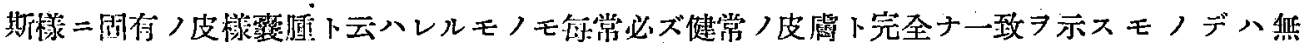

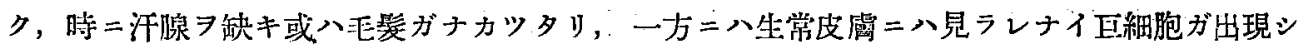
テ属タリスルコトガアル。(Goldmann, Kïnig, Cederbaum, Steuart, 原时)。

私ノ例デモ毛琵，皮脂腺

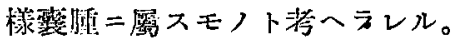

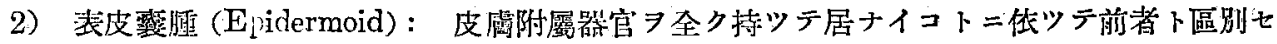
ラレル。深汇，萩崎，山时友ビ白崎氏等ノ例ハ之レ二屬シテ居タト報告サレテ居ル。

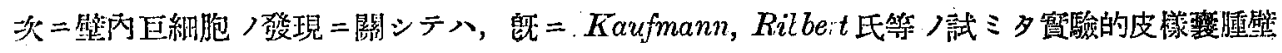

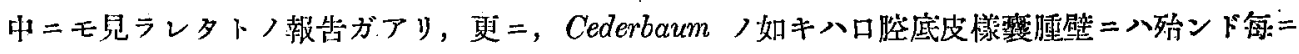

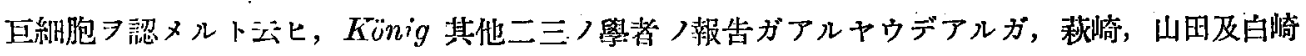

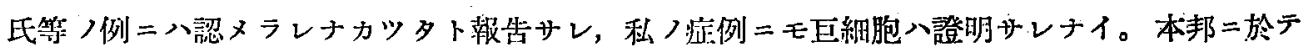

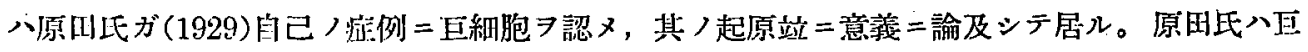

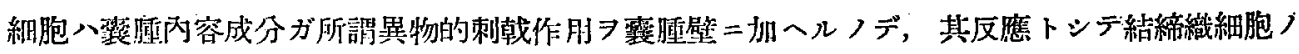

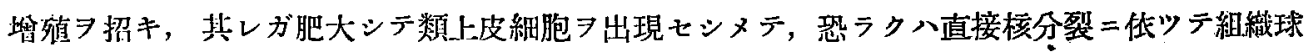
性異物多核巨細胞ヨ形成スルモノデアルト見做シ得ルト述ベテ居ル。

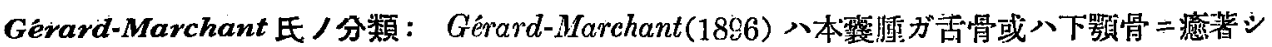
テ居ルコトカラ炏ノ如ク分類シタ。

a) Kystes dermoides adhyoidiens

b) Kystes dermoides adguniens

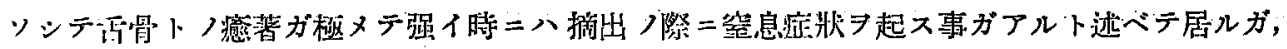




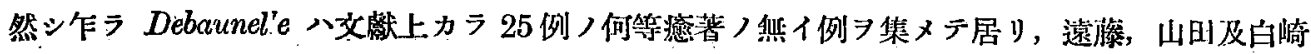
氐等！例ノ如ク全然䉥著八認メラレナイト報告サレタ例モアルノデ，斯㥞ナ症例ノ入ルベキ項

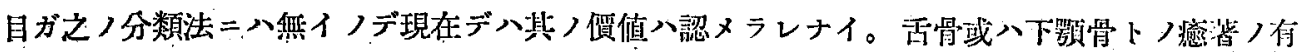

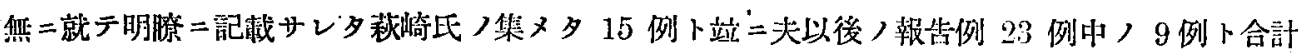

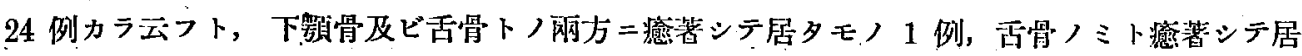

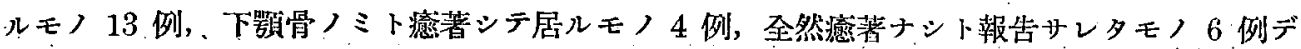

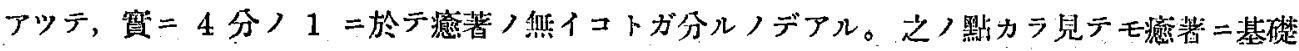
ヨ置ク分類法八問題トナラナイ。

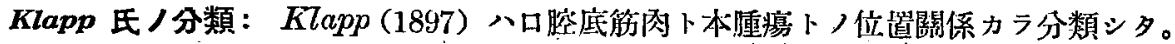

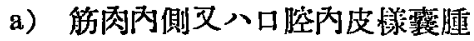

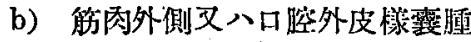

Barsclnickow（1924）八之ノ分類法二賛成シテ居ルガ，然シ之ノ分類法デハ腄㷬が增大シテロ 柼內及ビ頋下部ノ兩方二向ツテ弡育スル場合ガアルト云フ事實ヨ考虑シテ居ナイ。從テ之ノ分

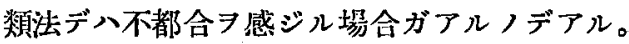

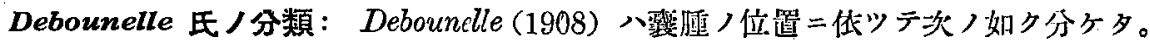

a) Mediane, davon obure am M. genioglossus, untere am M. geniohyoideus

b) Laterale über dem M. mylohyoideus

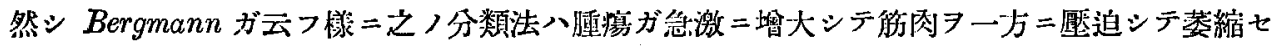

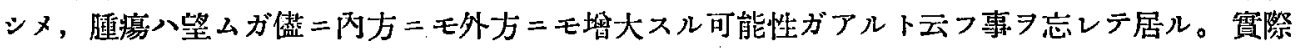

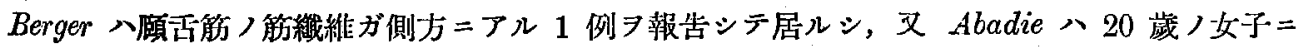

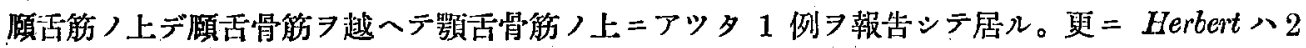

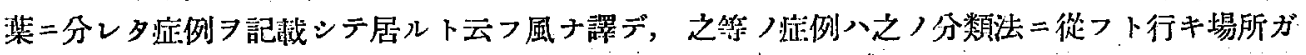
ナクナルノデアル。

\section{Bergmann 氏/分類}

a) 舌下部皮棁裂腫

b) 㮌下部皮樣塥腫

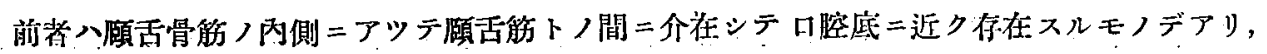

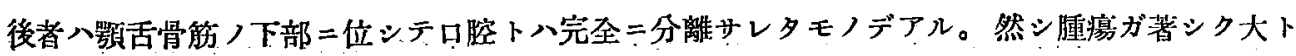

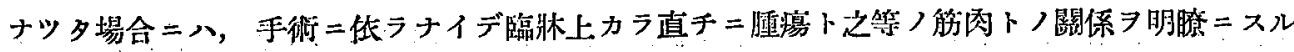
コトハ甚ダ困難ナモノデアツテ,結局 Klapp ノ分類ト同榜ナ不都合ヨ擢クコトトナル。其故二

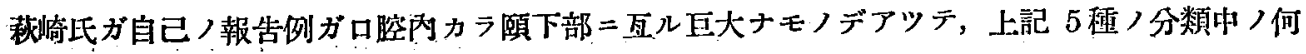

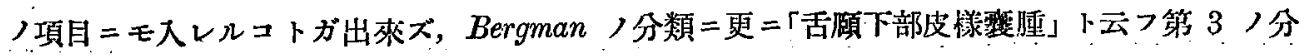

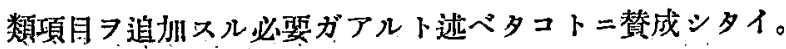


要スル =上拈 5 䅜ノ分類法ハ夫ネノ理由习持ツテ居ルノデアラウガ, Gérard-Marchant氏，

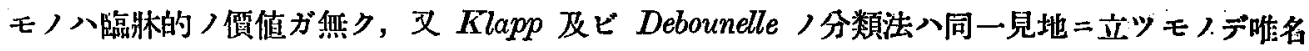
稱习異ニシテ居ルノミデアル。絬局Bergmann一萩㥓氏分類法卜モ云フベキモノニ從ツタ方ガ便 利デナル。

斯㥞ニ多クノ分類法ガ云ネサレル所以八，胎生期口腔底墢生ノ袘雜ナ゙裝置ガ發生經過中二發

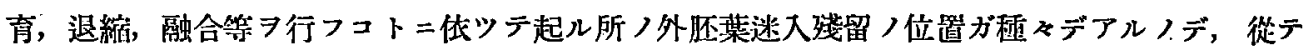

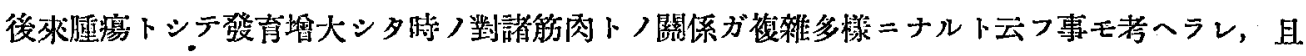

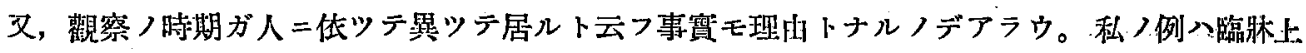

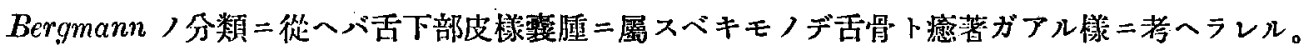

第 3 項 病理組織學的所見 :

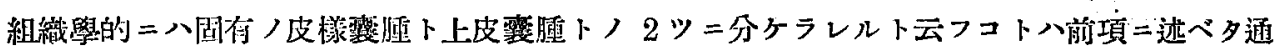
リデアル。之/兩者)發生上ノ關係=就テハTörök (1902)ガ Die Lehre von den Geschwülsten

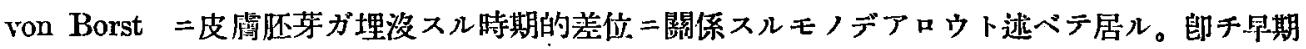

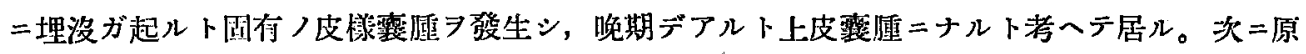

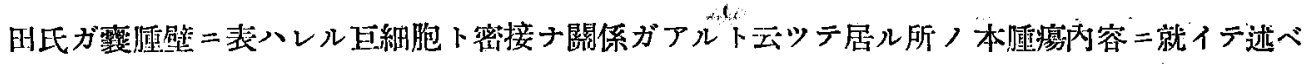
度卜思つ。

本邦例二於テ萩崎，澡汒，山时及ビ白崎氏等ノ見夕內容八，主トシテ皮脂腺分泌物，表皮剩 離嘚等デアツテ, 西洋デモ Debourelle, Cederbaum, Klapp, Abadie 等八同㥞ノ內容フ報告シテ

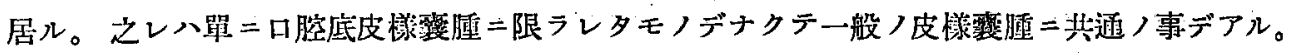

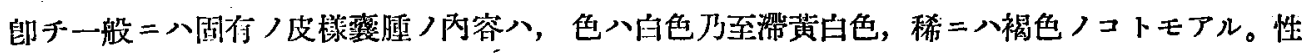

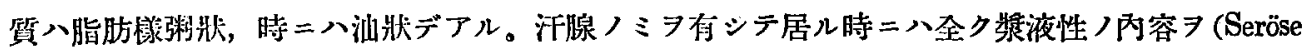
Dermoidcyste）示スコトモアル。更二稀二八原时氏ノ侧ノ如ク特有ノ脂肪球

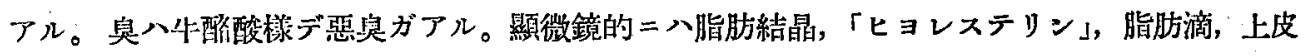

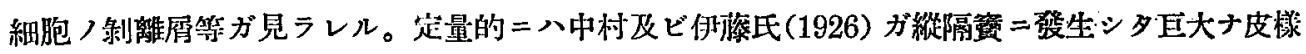

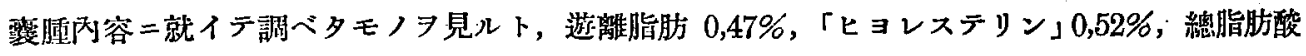

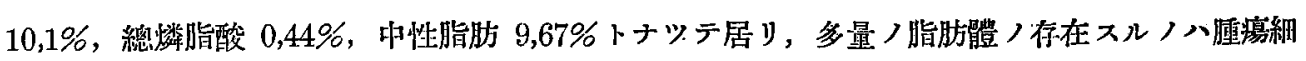

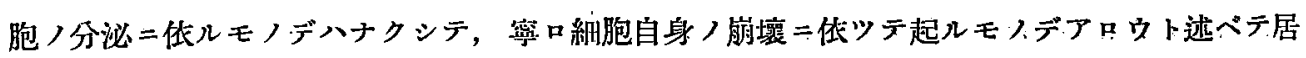

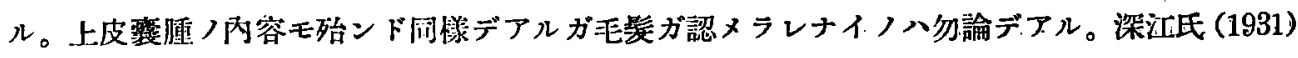

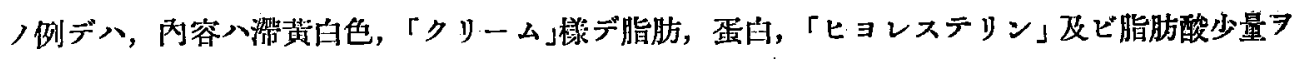
認又, 定量的二八水分 $80,5 \%$, 固形分 $19,5 \%$ ，其中，灰分 $0,351 \%$ ，中性脂肪 $5,050 \%$,

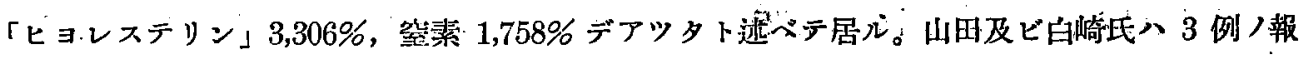

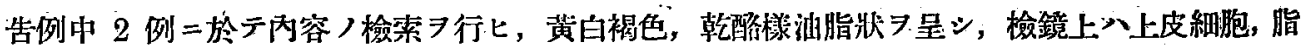

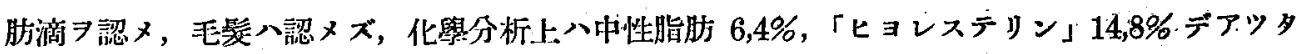
$-1070-$ 


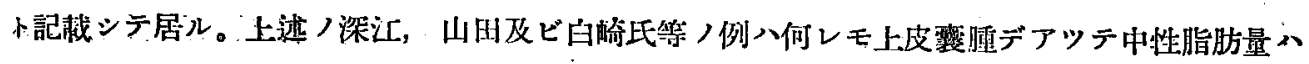

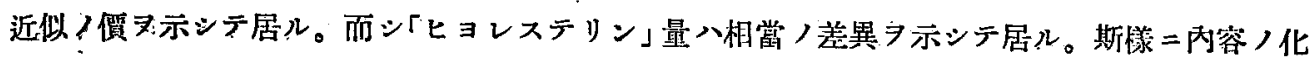

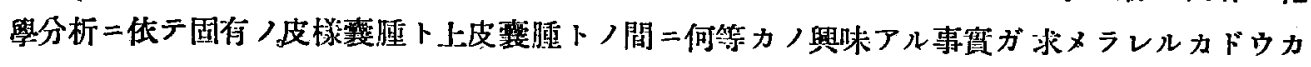
追加例ヨ期待スルモノデアル。私ノ例デハ內容八骂刺＝低ツテ得タモノデアツテ，色八黄褐色

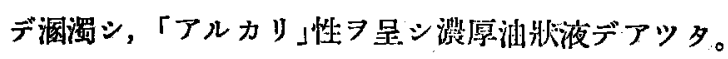

\section{第 4 項 頻 度}

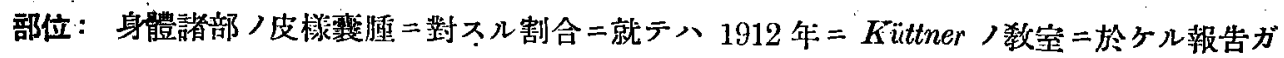

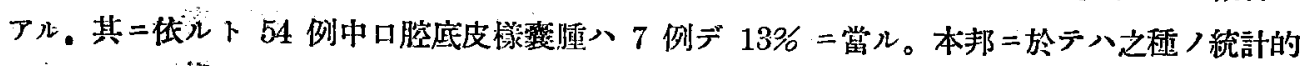
敬察八見ラレナイノデ制然トシナイガ, 恐ラクハKüttner ノ比卒ョリハ少ナイノデハフルマイ カ。次 = Bergmann／分類=從テ口腔底=於らル部位カラノ頻度

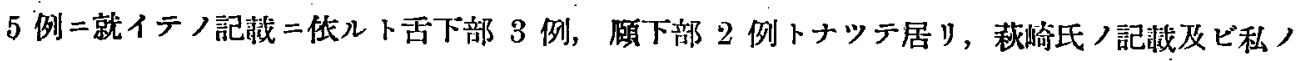
集×夕例 7 加へタ總計 59 例デ八, 舌下部 31 例, 傾下部 24 例, 舌㖽下部二互ルモ，4例デ アル。郎千舌下部ガ熶モ多イ。

瘾着ノ有热二依儿頻度二就イテハ前述シタ。

Ozenne (1883) ガ報告シタ 20 例中 15 例丈)䫏察カラ云フト正中線二生ジタモ，8例, 側 方二偏シテ出來タモ， 7 例デアル。Schnitzler (1890) ノ5 例デ八, 正中線=生ジタモつ只 $ノ 1$ 例デ殘リノ4 例八側方デアツタト云ツテ居ル。前記 Küttner，5例デ八正中=生ジタ モノ 4 侧, 側方偏在ノモノ 1 例デアル。一般二正楾=發生スルモノガ多イトサレル。

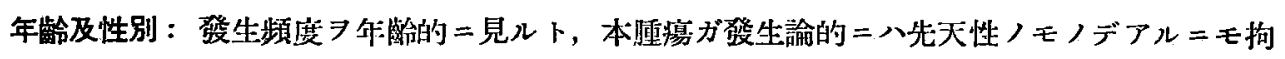

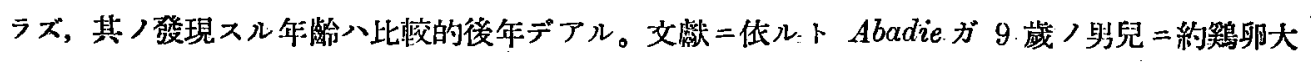
人舌下皮㥞露腫习認メタガ,夫レ八生後 6 ケ月目カラ存在シテ居タモノデアルト述ベテ居ル。之

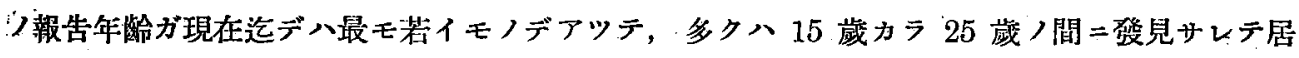
ルヤウデアル。Rolland 、 50 例中 33 例デ八 15 歲以下 4 例, 15-20 歲 27 例デ他 2 例

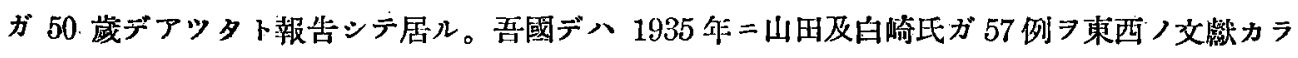
集メテ, 20 蔵以下八 18 例, 21-30 嵅八 26 例, 31-40 歳ガ 10 例, 41 歲以上八 3 例デアッ

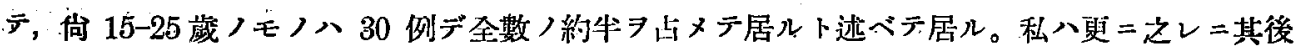
ノ報告例シ玑ベテ觀察シテ見ルト炏表ノ如クナル。

\begin{tabular}{c|c|c|c|c|c|c|c|c|c|c|}
\hline 年跲 & 初生兒 & $2-15$ & $16-20$ & $21-30$ & $31-40$ & $41-50$ & $51-60$ & $61-$ \\
\hline 例数 & 1 & 7 & 11 & .26 & 10 & 2 & 1 & 0 \\
\hline
\end{tabular}

郎チ初生兒ノ時代二增大シテ醫師二障礙フ訴へテ來ルト云フ㥞ナ例八誠二稀有ナ事デアッテ，

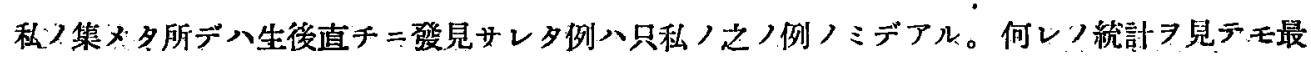

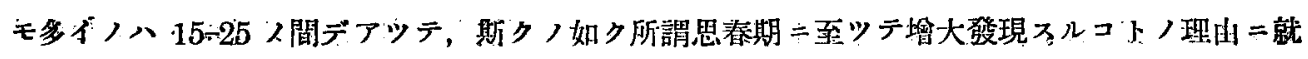




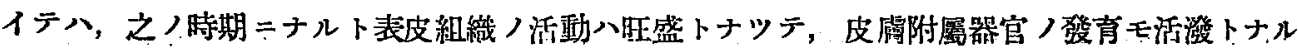

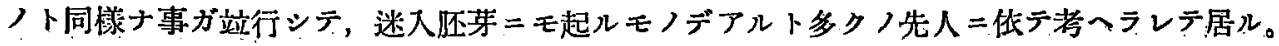
然シテ內分泌卜ノ關係=就イテハ明デナイガ多少,關係ガアルカモ知レヌ。

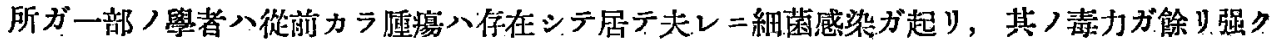

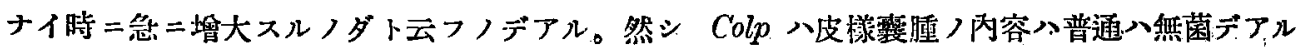
ト云ツテ細菌感染說ニ八反對シテ居ル。更二發育動機トシテ外賃ヨ考へテ居ル人モアルガ，山

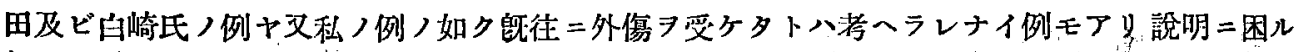
ノデアル。然シ外傷刺戟が發育习速進サセル要素トナリ得ルト云フ事ハ容易二考へラレル。私

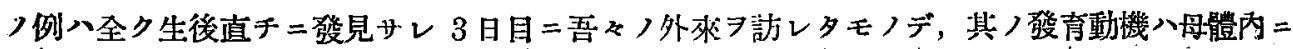
胎兒トシテ生活シタ時代二求メルョリ他ハナイ。

次二性別二頻度尹見ルト山田及ビ白崎氏八 58 例中男子 26 例, 女子 32 例デアッテ女子， 方ガ多イト記掝シテ居ル。其ノ後つ報告例 7 追加スルト女子 34 例，罗子 28 例卜ナル。

即于思春期ノ女子二多イト云フ事ニナル。

\section{第 5 項 症侯}

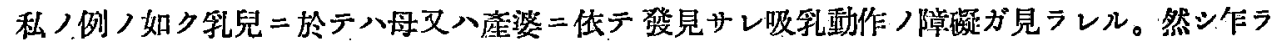

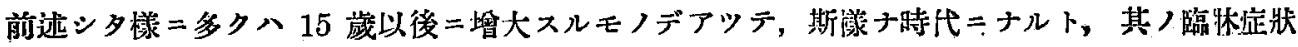
八多分二腫演ノ大サ站=局所解剖學的關係二低ツテ左右サレルモノデアル。其つ故 $=$ Bergmann ノ分類ニ從テ $3 \%$ 分ケデ觀察スルノガ安當デアル。

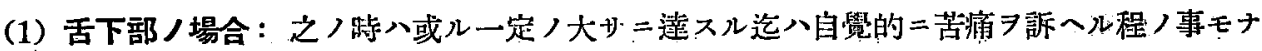
ク, 從テ醫師习訪レルコトモ少ナイ。何カ他ノ口腔內疾患つ爲二診察习受らテ偶然二發見サレ

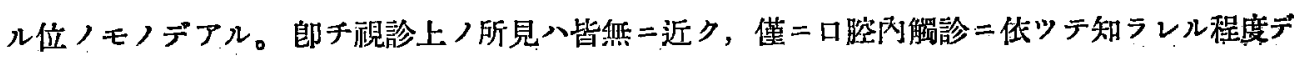
アル。多クハ正中線二增大スルガ例外モアル。大サ 增加スルニ從テ活习硬口蓋二向ツテ壓迫

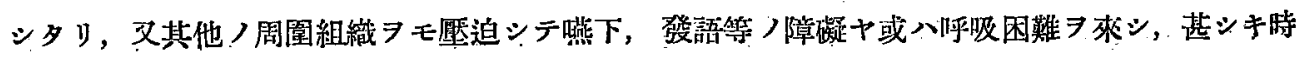
八瀕死ノ爿態トナルコトモアル。萩崎氏ノ例八特二呼吸困難が强クテ瀕死！状態ニナツテ居タ

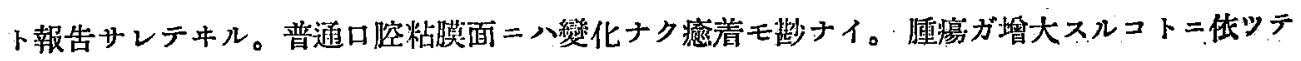

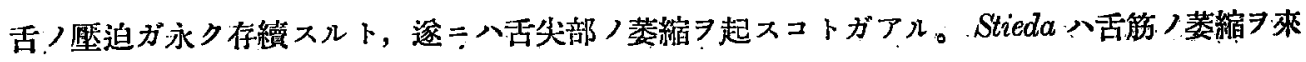
シタ 1 例 報告シテ居ルガ, 私ノ例二於テモ舌尖部ノ短縮ガ著明デアル。

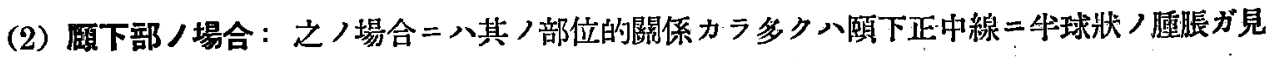

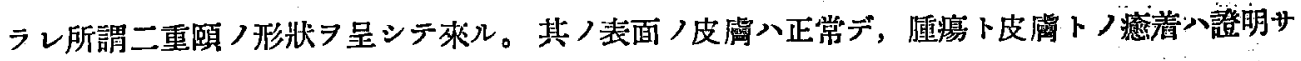

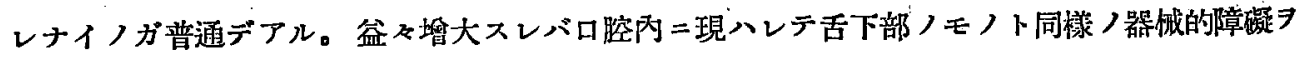
招來スルコトンル。 。

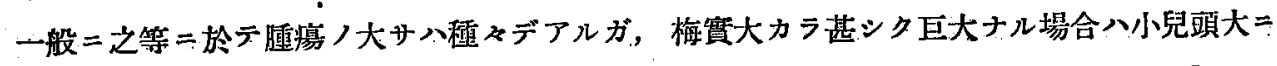
モナルコトガアル。形狀八侮常殆ンド生球狀二見ラレルガ摘出標本二就イテ見ルト Herbert ， 
朝告ノ如ク二葉性二發育シタモノモアル。皮膚站二ロ腔粘膜卜ハ密接ナ關係タ持ツテ居ナイノ

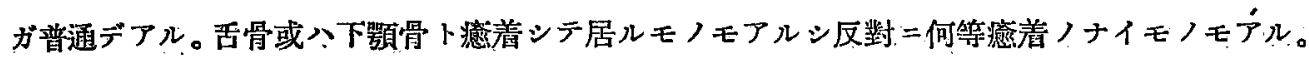

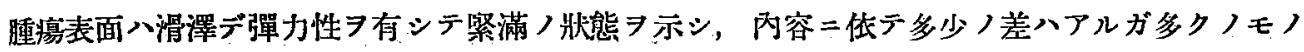

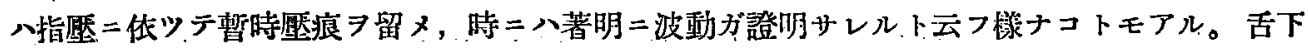

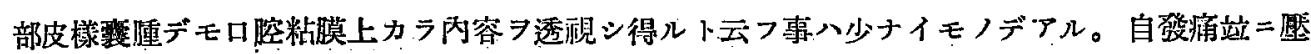

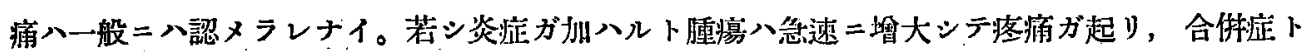
シテロ腔底蜂裔織炎习惹起シテ重篤ナ証狀ヨ呈スルコトガアル。斯ル感染化膿八外傷或八試驗

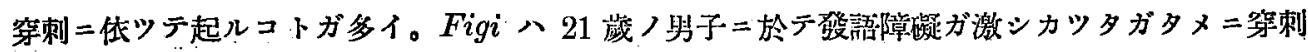
術

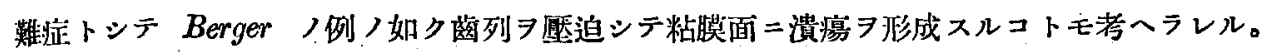

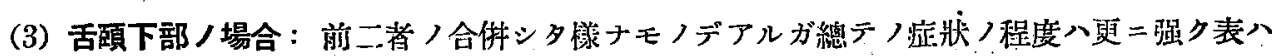
レル.

\section{第 6 項 猃 斷}

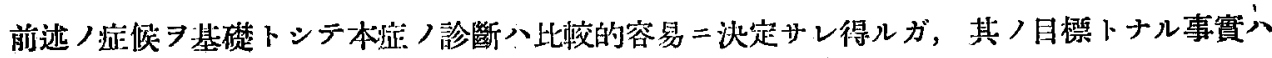
要スル所, 次ノ如キモノデアル。

（1）本症へ多ク口腔底正中二發生シテ，主トシテ思春期ノ久ニ多イコト。

(2) 大サ八種 $゙$ デ梅䐝大ョリ小兒頭大ニモ及ブコト。

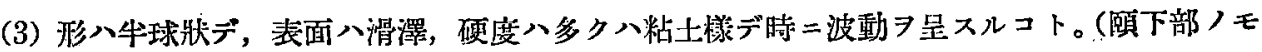
ソ 2 重櫃 7 呈スルコト)。

（4）壁八此較的厚クテ指壓二依り壓痕ヨ生ズルコト。

（5）皮盧，粘膜ト瘾着ナキコト。

（6）疼痛 缺如シテ居ルコト。

(7) 單房性デアルコト。

（8）試驗穿刺＝依ル內容檢查。（但シ目的习详シナイコトガ多イ。）

即千之等ノ事ヨ注意スレバ多クハ診斷习下シ得ルガ, 時二八亦, 極メテ困難ナコトガアル。若 シ組織學的二研究シ得レバ診斷八正碓デアルガ, 之レ八術前二必ズ行へルトハ云へナイ。從テ 本症卜鑑别スベキ笶患二就イテ調ベテ見ル必要ガアル。

本症ト鑑別习必要トスル疾患二八次ノ梯ナモノガアル。

\section{(1) 蝦茧腫 (Ranula)}

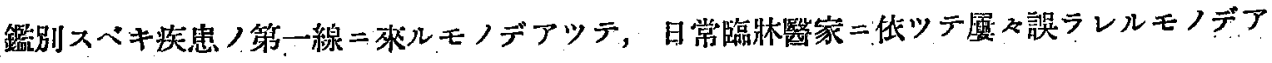

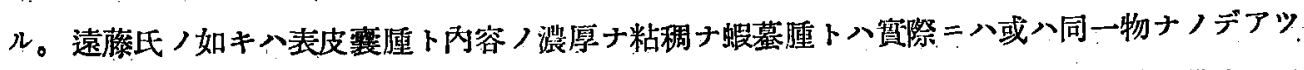
テ, 各々巽ツタ二方面カラ研究サレタノデハアルマイカト想像シ，明碓ナ區別八附ら難イト云

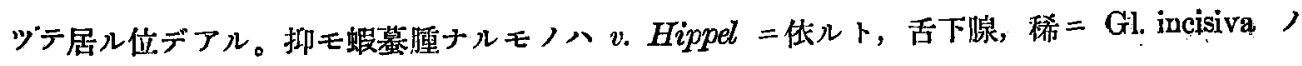




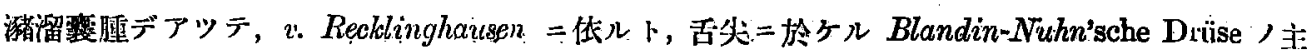

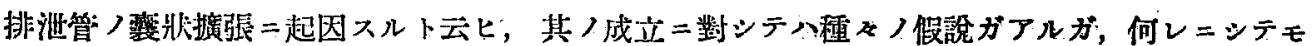

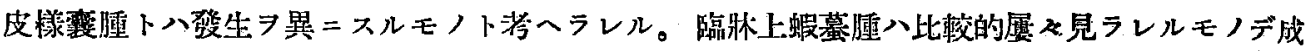
人三多イ。發生部位入多ク舌下ノ一方二偏シテ起少中線二原發スルコトハ少ナイノデアルガ;

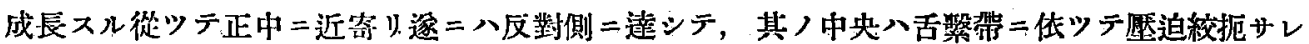
テ，一見シタ所デハ兩側性=發生シタカノ如ク見ェルノデアル。圣願下部二向ツテ垻大スルコ

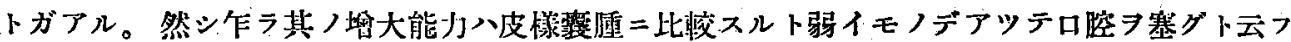

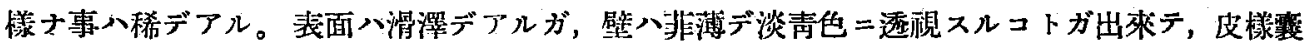

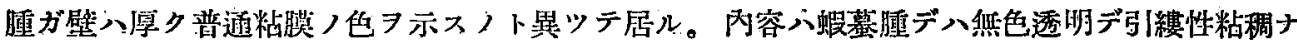
液體デアツテ紧二第刺スルコトガ出來，外表カラハ波動ガ著朋二證明サレル。都筑教授二作ル

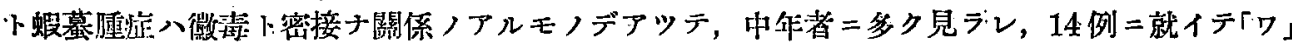
E反應 7 檢查シタ所ガ陽性 10 例，陰性 4 例デアツタ，更二同教堂つ高橋氏八組織學的二調查

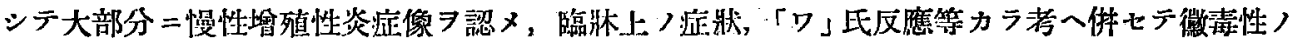

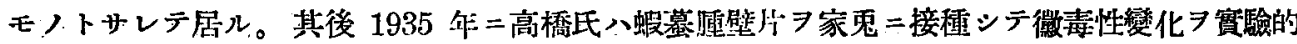

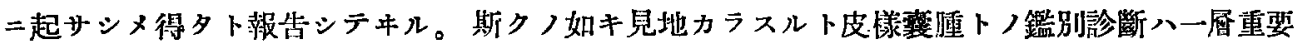

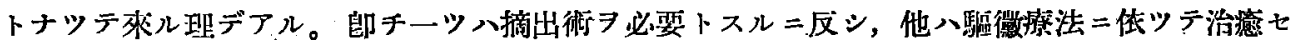
シメ得ルノデアル。私ノ例二於テハ非出氏應應 檢シタガ陰性デアッタ。

-(2) 粉 瘤

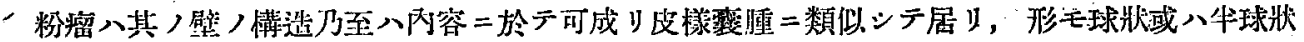

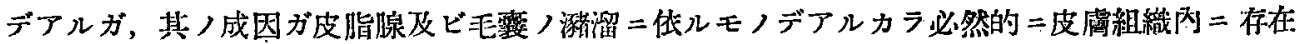

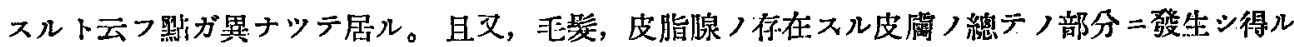
ノデアッテ, 皮㥞雴腫ノ如ク裂溝ノ融合スル部分＝發生スルト云フ事ハナイ。

(3) 脂肪腫

之レ八正中線二發生スルコトハ稀有デ，多ク八扁側性二來リ；他ノ體部二於ケル脂肪腫卜同 栐二相對性二棑ルコトガ多イ，且ツ分葉狀

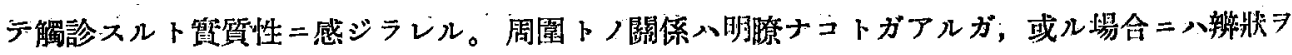
ナシテ皮下組織中へ數多/笑起出シテ居ルコトモ少クナイ。

(4) 血管腫

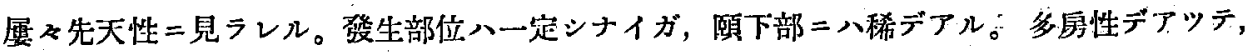

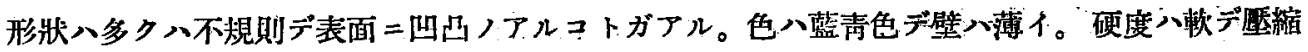
性ガ極メテ著明デアル。网容八流血デアツテ頭部シ下ゲルカ，凤ハ努責二依ツテ紫張增太スル コト等八皮様硛腫卜異ナル所デアル。

\section{(5) 淋巴管腫}




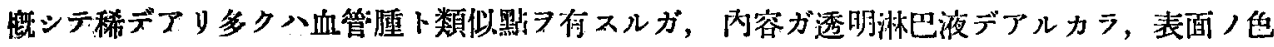

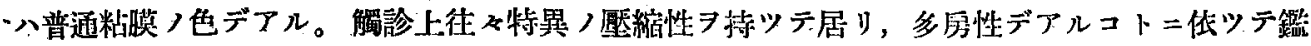
别サレル。

(6) 鳃满要腫

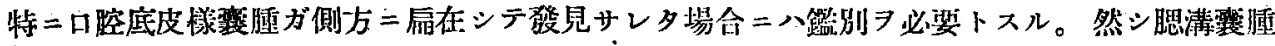
ハ多クハ側頸部＝向ツテ發亩スルモノデ，口㻠內二向ツテ著シク増大スルコトハナイ。

\section{第 7 項 强後}

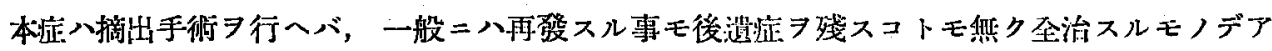

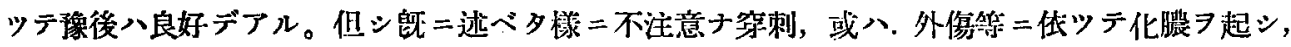
更二進ンデハ自潰シタリ，不装ナ場合二八ロ腔底蜂简織炎习招隶シ生命

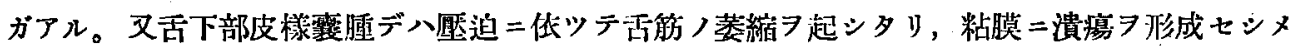
タリスルコトガアル。一般二皮樣型腫ガ大シタ器珹的障礙モナク永ク經過スルヤウナ場合二八

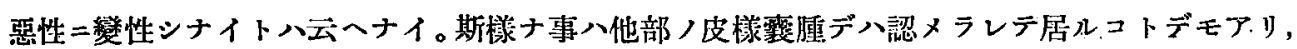
殊二高年者二於テハ癌腫二變性シ得ルコトモ考虑スベキデアラウ。

\section{第 8 項 療 ：法}

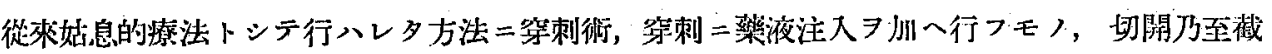
斷ヨ行ツテ殘留部ラ硝酸銀, 酸化亞鉛等 八早晚再發ヨ起スノデ，現在デハ根治療法トシテ，乎術二低ツテ全摘出ヨ行フノガ最良ノ方法

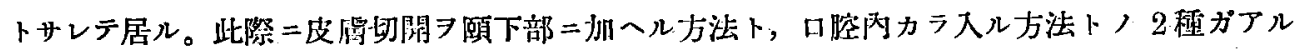

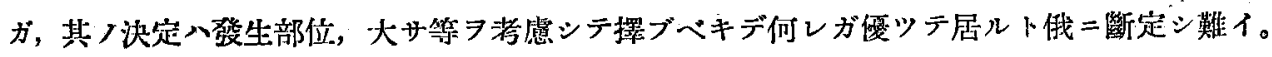

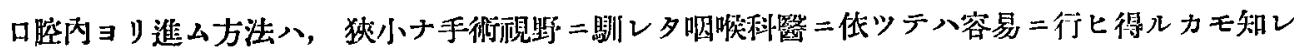

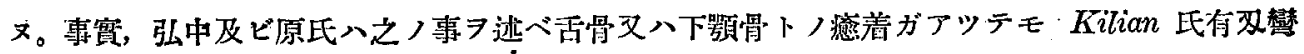

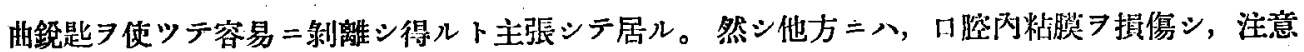
深ク行ハナイトロ腔內ノ細菌感染ヨ招來スルト云フ缺點ガナイデモナイ。萩崎氏ハ氏自身ガ耳

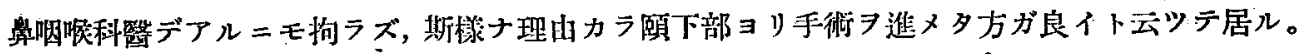

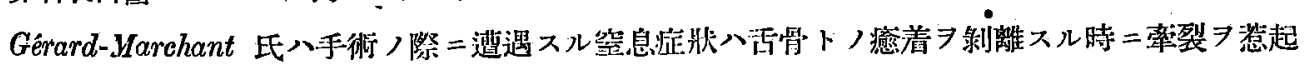
スルガタメ二起ルト云ヒ，Klapp 八舌骨ヨ摃傷シテ呼吸困難ヨ來シタ患者二巳ムナク氣管:四開

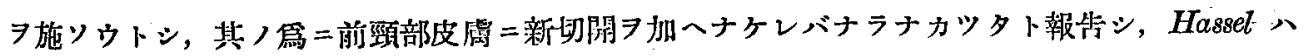

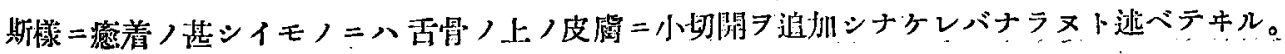

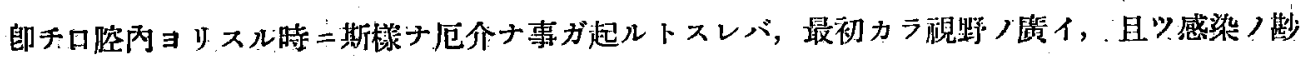
ナイ頋下部カラ始メタ方ガ得策ノヤウ二考へラレル。䝠下部二於ケル切開線ノ方向八縱，横， 兩方方胕ヒラレテキル。縱切開デ八虑着ガナイ時二八解肉フ切斷スルコトナク剔出シ得ラレル。

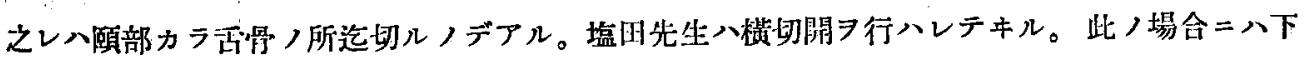




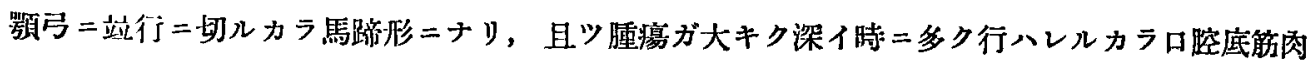

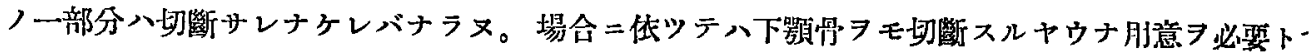
スルコトモアラウ。

要スル 何レノ方法シ罩ブトシテモ, 全摘出術コソ行ハルベキ最良ノ方法デアル。私ノ例= 於テハ患者ガ生後 3 日目ノ乳兒デアルタメ二，唯出爽ル丈多クノ部分习切除シタ二止メタ。即

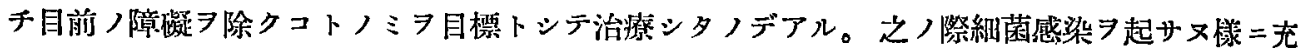

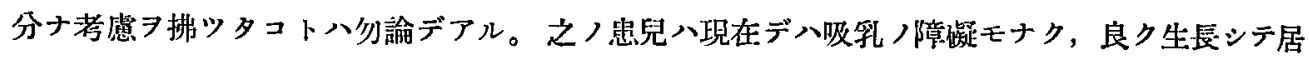

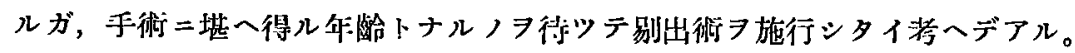

\section{第 IV 章 總 括}

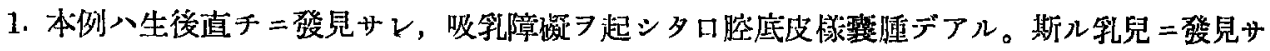
レタ報告例ハ見當ラナイ。

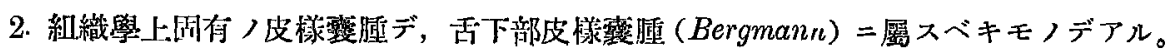

3. 一般論娎約

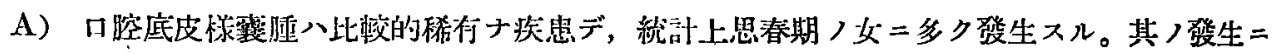
就イテハ胎生學上ヨリ推諭サレ，一般二胎生期＝外还集ガ中㗏葉中二異常埋浚シ或八迷入 セルタメトサレル。然シ迷入埋沒ノ局所二至ツテハ諸說アリ，明碓ナ解答八與へラレテキ ナイ。

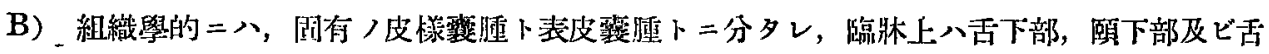
願下部ノ 3 ツ分類スベキガ姿賞デアル。

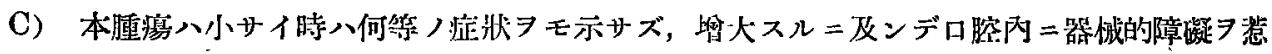
起スル。

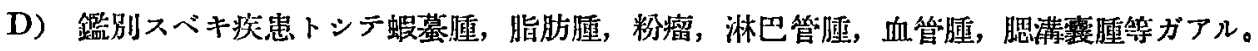

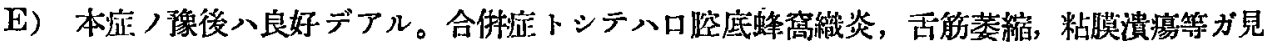
ラレル。稀デハアルガ最惡ノ場合トシテ癌性變性ガ舉ゲラレル。

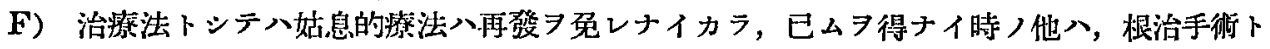

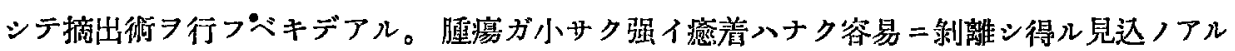
场合ニ八口腔內ョリ，然ラザレバ卧部ョリ進ムべキモノト洘へル。

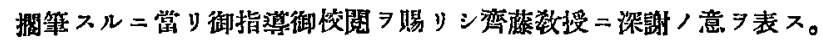

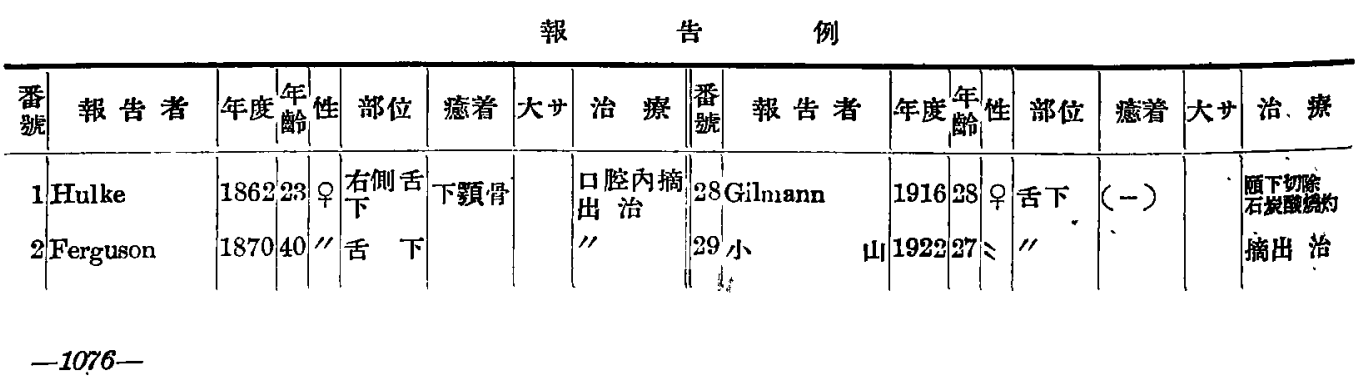




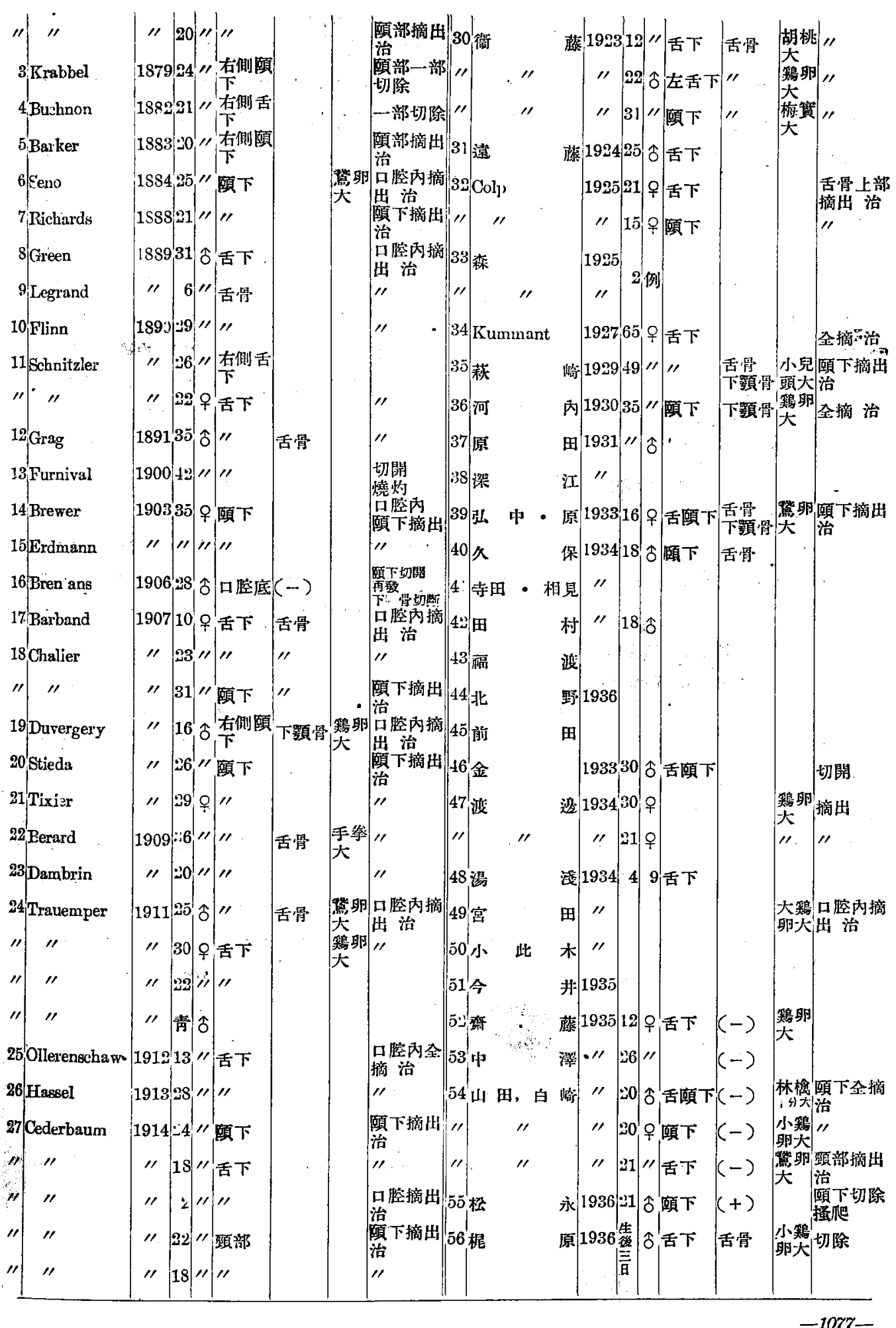




\section{文獻}

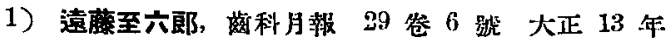

2) 衞藤崖, 日本外科學會雜誌 24 回 1097

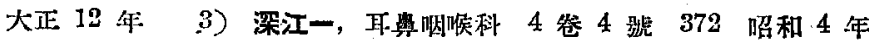

4）福渡六郎，耳艒咽喉科臨

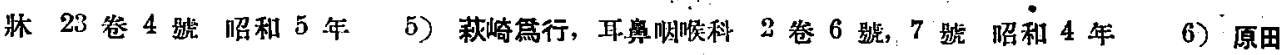

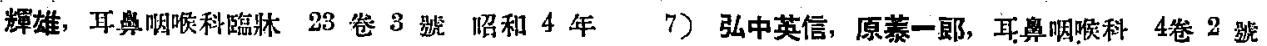

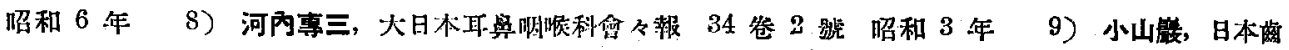

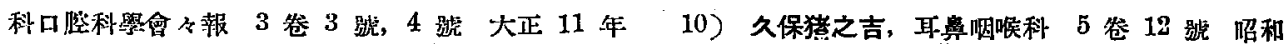

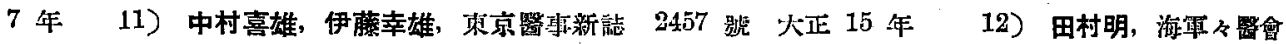

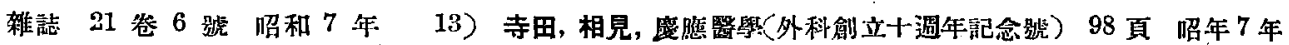

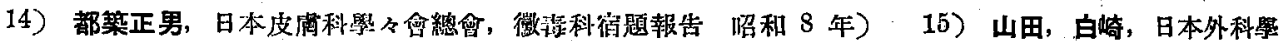

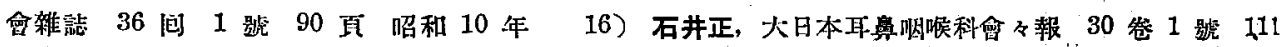

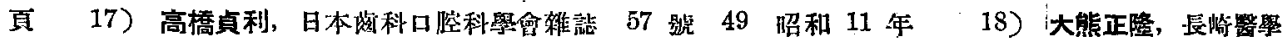

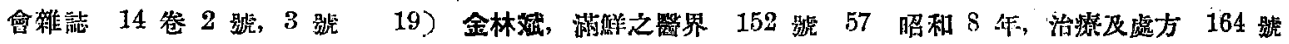

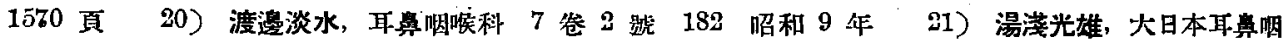

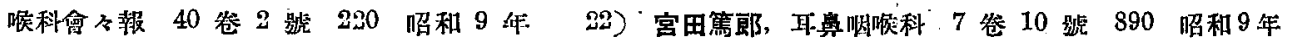

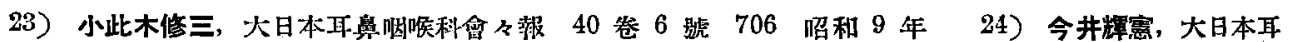

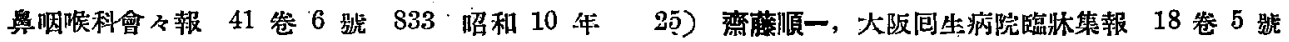

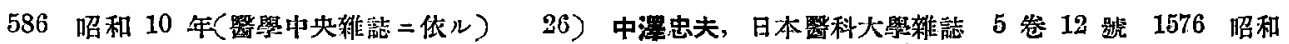

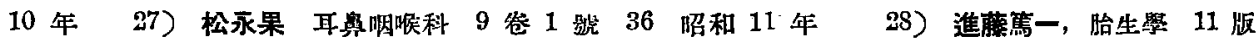
89) Baryschnikow, Zent. org. f. d. ges. Chir. u. ihre Grenzgeb. Bd. 31,S. 599. 30) Bergmann, Handbush der prak. Chirurgie. 4 te Auf. Bd. I, S. 976, Stuttgärt. 31) Cederbaum, Bruns Beitrïge zur Klin. Chir. Bd. 83, H. 1., S. 92, 1914. 32) Colp, Surg., Gynaerol.; and Obstetr., Vol. XL, 1925. 33) Debounelle, Les Kystes dermoides du plamcher de la bouche, Paris, 1908 Handbuch d. prak. Chir. 6 te Auf, 1926 及ビ Colp =依ル) 34) Figi and Harrington, Surg. Clin. N. Ames., 9, S. 89, 1939 (Zent.-org. f. d. ges. Ghir. u. ihre Genzgeb. Bd. 47, S. 256) 35) Hassel, Bruns Beiträge zur klin. Chir. Bd. 83, \&. 332, 1913. 36) Klapp, Brnns Beitrïge zur klin. Obir. Bd. 19, H. 3, S. 606, 1897 37) K̈̈nig, Arch. fii Klin. Chir. Bd. 48, S. 164, 1894. 38) Mertens, Beitrige zur klin Chir. Bd. 31, S. 516, 1901. 39) Remark, Die Lehre von der Geschwülsten von Borst. Bd. 2, S. 8 \&, 190د. 40) Rolland, Handbueh d. prak. Chir., 6 te Auf., Bd. 1, 1926. 41) Stieda, Münch, med. Wschr., S. 1046, 1909. 42) Türök, Die Lehre vón den. Geschwülsten von Borst. Bd. 2, S. 838, 1902. 43) John Chalmers Da costa, Keen's Surgery V. III, S. 683.1919.

附圖說明

訝一圖 術前撮影

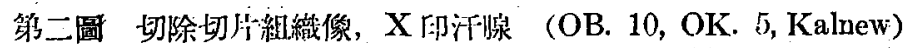




\section{枟原渝文附涸 \\ 第一浻}

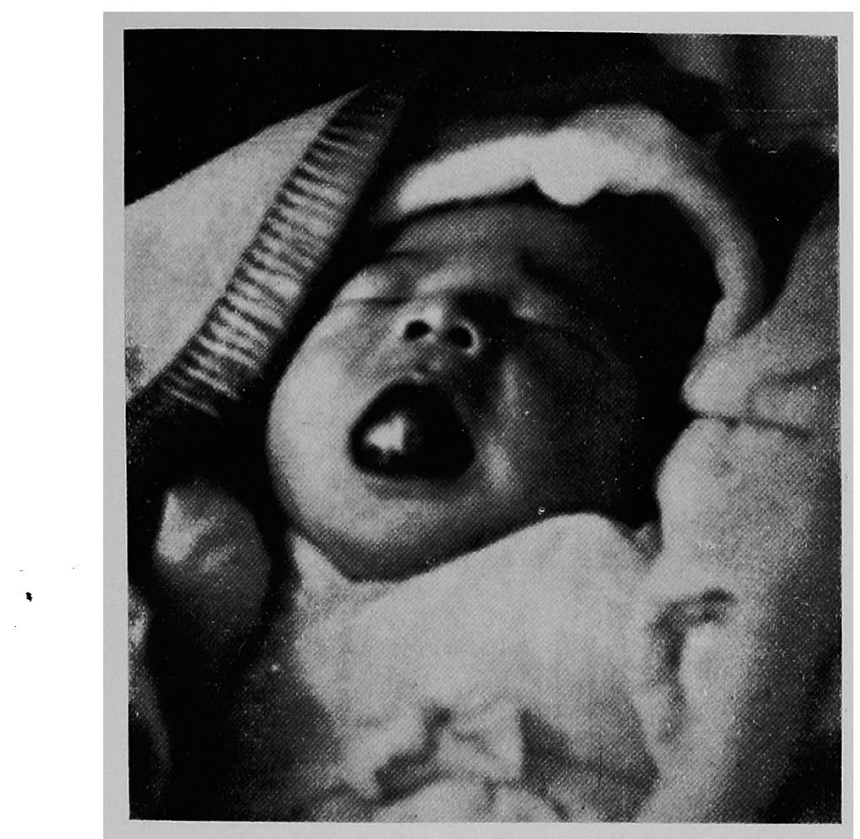

第 二 圖

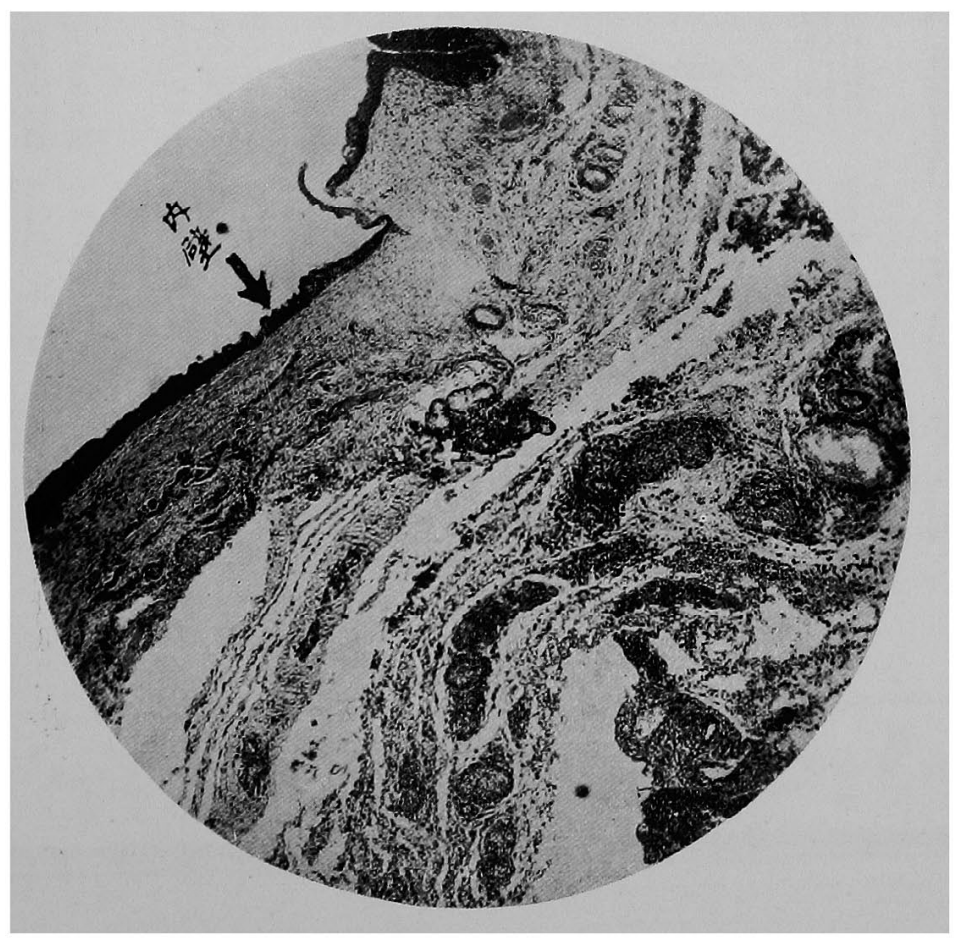

